\title{
The Regulatory and Operational Framework of Microfinance Banks on Consumers in Nigeria: An Appraisal
}

\author{
Enyia, Jacob Otu ${ }^{1 *}$, Inyang, Patricia Endeley ${ }^{2}$ \\ ${ }^{I}$ B.Sc. MBA, LL.B., B.L., LL.M, Ph.D., is a senior Lecturer in the Faculty of Law, Unical \\ ${ }^{2}$ LL.B., B.L., MA (International \& Comparative Business Law) is a Lecturer in the Faculty of Law, Unical \\ *Corresponding Author: Enyia, Jacob Otu, B.Sc. MBA, LL.B., B.L., LL.M, Ph.D., is a senior Lecturer \\ in the Faculty of Law, Unical
}

\begin{abstract}
This work is aimed at appraising the impact of the regulatory and operational framework of microfinance banks on the consumer. It is illicited by the current negative complaints on the role of microfinance banks in the economy generally and consumers in particular since its birth. Generally, the banking industry is so strategic to the economy that naturally, everybody is a stakeholder. It act as lubricants of the economy custodians of the payment system, saving mobilization, financing trade, agriculture, industry, consumer activities, stimulate economic and assist consumers in providing micro credits. The cost of credit as evidenced in the high interest rate, the non-availability of branches in many rural communities and incessant distress of many micro-finance banks has become a source of concern for consumers who are gradually losing confidence in the system. The paper has examined the impact of the regulatory and operational framework and identified inhibitions and make recommendations for repositioning for better service delivery especially in the emerging digital age in banks operation.
\end{abstract}

Keywords: Microfinance, Consumers, Banks, Economy Microcredit, Regulatory, Operational.

\section{INTRODUCTION}

Robust economic growth cannot be achieved without putting in place well focused programmes to reduce poverty through empowering the people by increasing their access to factors of production, especially credit. In line with this reasoning therefore, it is no mere coincidence that the Central Bank of Nigeria (CBN) introduced Nigeria's first Microfinance Policy Framework in December 2005, barely three months after the United Nations General Assembly adopted $2005^{1}$ as the International Year of Microcredit to "address the constraints that exclude people from full participation in the financial sector". ${ }^{2}$ The rationale was that no robust, people-based growth can be achieved without increasing the access of micro-enterprises and the economically active but poor citizens to factors of production, especially financial services to empower them.

The entrepreneurial capacity of the poor which are capable of being developed, was believed, would be significantly enhanced through the provision of microfinance services to enable them engage in economic activities and be more self-reliant, increase employment opportunities, enhance household income and create wealth. This, the traditional microfinance services practiced by this group could not give any meaningful outcome.

After five years of operating this Policy, the CBN undertook a comprehensive review of developments in the sub-sector and discovered that although some improvements such as a heightened awareness among stakeholders and broad service provisioning (as opposed to the narrow microcredit focus) had taken place, a large percentage of Nigerians are still excluded from financial services ${ }^{3}$, hence called for a revised of the policy framework in 2012.

It is in line with the foregoing, that this paper intends to examine the regulatory and operational framework on microfinance banking and the impacts on the consumer. A brief consideration of

\footnotetext{
${ }^{1}$ InternationaI Year of Microcredit 200, www.un.org/en/events/,astevents/mjcrcrecjit 2005, Accessed 21/9/2014.

${ }^{2}$ Draft National microfinance Development Strategy' (for discussion and comments only) p. 1

${ }^{3}$ ibid
} 
The Regulatory and Operational Framework of Microfinance Banks on Consumers in Nigeria: An Appraisal

emergence of microfinance banking, how it operates and the challenges therein shall ' $\mathrm{L}$ also be highlighted with some recommendations.

\subsection{Emergence of Microfinance Banking in Nigeria}

Since the advent of microfinance banking in Bangladesh ${ }^{4}$ in the mid 1970's, several countries have copied this financing model. The seeming popularity of the model among developing countries is predicated on poverty reduction prospect it offers.

In Nigeria, the practice of microfinance is culturally rooted and dates back several centuries. The traditional microfinance institutions provide access to credit for the rural and urban, low-income earners. They are mainly of the informal Self-Help Groups' (SHGs), Rotating Savings and Credit Associations (ROSCAs), accumulating credit and savings associations (ASCAs) and direct borrowings from friends and relations ${ }^{5}$. Other providers of microfinance services include savings collectors and co-operative societies. The informal financial institutions generally have limited outreach due primarily to lack of funds to advance to its clients as loans as at and when required.

These approaches may have sufficed in the traditional society but the growth in the sophistication of the economy and the increasing incidence of poverty among citizens has revealed the shortcomings of this approach calling for government intervention for the benefits of the consumers.

Therefore, in order to enhance the flow of financial services to Nigerian rural areas, Government has, in the past, initiated series of publicly-financed micro/rural credit programmes and policies targeted at the poor. Notable among such programmes were the Rural Banking Programme, sectoral allocation of credits, a concessionary interest rate, and the Agricultural Credit Guarantee Scheme (ACGS). ${ }^{6}$

Other institutional arrangements were the establishment of the Nigerian Agricultural and Co-operative Bank Limited (NACB), the National Directorate of Employment (NDE), the Nigerian Agricultural Insurance Corporation (NAIC), the Peoples Bank of Nigeria (PBN), the Community Banks (CBs), and the Family Economic Advancement Programme (FEAP). In 2000, Government merged the NACB with the PBN and FEAP to form the Nigerian Agricultural Co- operative and Rural Development Bank Limited (NACRDB) to enhance the provision of finance to the agricultural sector. It also created the National Poverty Eradication Programme (NAPEP) with the mandate of providing financial services to alleviate poverty. ${ }^{7}$

Microfinance services, particularly sponsored by government, have adopted the traditional supply-led, subsidize credit approach mainly directed to the agricultural sector and non-farm activities, such as trading, tailoring, weaving, blacksmithing, agro- processing and transportation Although the services have resulted in an increased level of credit disbursement and gains in agricultural production and other activities, the effects were short-lived, due to the unsustainable nature of the programmes. ${ }^{8}$

It was in a bid to resolve this identified deficiency of the informal microfinance sector that the CBN in 2005 introduced a microfinance policy, a prelude to the licensing of microfinance banks in Nigeria which led to the current microfinance banking finance scheme. This was founded to provide finance to economically active poor, excluded from financing by conventional banks, provide employment, engender rural development and reduce poverty. However, the current scheme, Microfinance banking' is not also without challenges as will be reviewed later in this paper.

Microfinance banks were therefore established because of the failure of the traditional microfinance style and the various concerted efforts by the governmental approaches to adequately address the financing needs of the poor and low income groups. ${ }^{9}$ The CBN further justified its licensing of

\footnotetext{
${ }^{4}$ 1.A.Acha, 'Microfinance Banking in Nigeria: Problems and Prospects' International Journal of Financing and Accounting, 1(5), (2012) p.105.

${ }^{5}$ G.C.Okpara, 'Microfinance Banks and Poverty Alleviation in Nigeria', Journal of Sustainable Development in Africa, (2010), p.117.

${ }^{6}$ Microfinance Policy, Regulatory and Supervisory Framework for Nigeria', (Abuja: Central Bank of Nigeria, 2005), p. 5,6.

7 ibid

${ }^{8}$ ibid

${ }^{9}$ I A.Acha, op.cit.
} 

Appraisal

microfinance banks with the lack of institutional capacity and weak capital base of existing community banks, existence of huge un-served market and need for increased savings opportunity. ${ }^{10}$

\subsection{What is Microfinance Banking}

According to the CBN Revised Regulatory and Supervisory Guidelines for Microfinance Banks in Nigeria, a microfinance bank (MFB), unless otherwise stated, shall be construed to mean any company licensed by the CBN to carry on the business of providing financial services such as savings and deposits, loans, domestic fund transfers, other financial and non-financial services to microfinance clients". ${ }^{11}$

Microfinance is the provision of financial services to the poor who are traditionally not served by the conventional banks. These financial services include credit, savings, micro-leasing and money transfer and payment services. ${ }^{12}$

The features that distinguish microfinance from other forms of formal financial products are; smallness of loans advanced and savings collected, near absence of assets-based collateral and simplicity of operations. ${ }^{13}$ It can be deduced from the foregoing that microfinance is a poverty alleviation strategy which operates by providing credit and other financial services to economically active but low income households and their businesses, reduce vulnerability to shocks and create employment. ${ }^{14}$ Describing microfinance bank with Ekondo microfinance as a case study, a television producer said; 'the bank gives high interest rate, easy opening of account with less than five minutes spent, have no risk or minimal risk and so investment are secured. ${ }^{15}$

\subsection{The Goals of Microfinance Banks}

The establishment of microfinance banks has become imperative to serve the following purposes ${ }^{16}$ :

- Provide diversified, affordable and dependable financial services to the active poor, in a timely and competitive manner, that would enable, them to undertake and develop long-term, sustainable entrepreneurial activities;

- Mobilize savings for intermediation;

- Create employment opportunities and increase the productivity of the active poor in the country, thereby increasing their individual household income and uplifting their standard of' living;

- Enhance organized, systematic and focused participation of the poor in the socio-economic development and resource allocation process;

- Provide veritable avenues for the administration of the micro credit programmes of government and high net worth individuals on a non-recourse case basis. In particular, this policy ensures that state governments shall dedicate an amount of not less than $1 \%$ of their annual budgets for the on-lending activities of microfinance banks in favour of their residents;

To achieve these goals, reliance must be made on the regulatory framework instituted by CBN; a microfinance policy framework for the operation of these category of bank.

\subsection{Regulatory and Operational Framework}

The regulatory environment of microfinance bank is dominated by the Central Bank of Nigeria (CBN) who provides the policy and the regulatory guidelines to drive microfinance in the country while also

\footnotetext{
${ }^{10} \mathrm{CBN}$ Microfinance Policy, op.cit.

${ }^{11}$ ibid

${ }^{12}$ E.F.Eboh, Changing Development Paradigms via Microfinance Banks', African Journal of Entrepreneurship1(1), (2008), p.52

${ }^{13}$ D. lorchir, Reducing Poverty in Benue State of Nigeria: The-Role of Microfinance and Micro-Enterprises' Journal of Business Management, 1(2), (2006), P.15

${ }^{14}$ M. Yunus\& J. Alan,' The Banker to the Poor: Micro-lending and Battle against World Poverty', Public Affairs, (1999), p.62.

${ }^{15}$ O.Peter, 'Ekondo Bank Buisness Time', CRBC TV Production, 22/9/2014.

${ }^{16}$ Microfinance Policy, op.cit. p.12-13.
} 

Appraisal

serving as the regulator to the sector. It is important to note that there is over nine (900) hundred microfinance banks today in Nigeria and they are all regulated and supervised by the CBN. ${ }^{17}$ In light of this, the need for a regulatory framework for microfinance banks in the country has come under consideration with the formulation of a policy; the Central Bank regulatory and Supervisory Guidelines for Microfinance Banks in Nigeria (as revised in 2012).

\subsection{The Central Bank regulatory and Supervisory Guidelines for Microfinance Banks in Nigeria (as revised in 2012)}

This policy has been prepared in exercise of the powers conferred on the Central Bank of Nigeria by the provisions of Section 57(1) of the CBN Act ${ }^{18}$ and in pursuance of the provisions of Sections 5861(a) of the Banks and Other Financial Institutions Act [BOFIA]. ${ }^{19}$

The provisions of the Guidelines include but are not limited to the following;

\section{TERMS AND DEFINITIONS}

\subsection{Microfinance Bank}

A microfinance bank (MFB), unless otherwise stated, shall be construed to mean any company licensed by the CBN to carry on the business of providing financial services such as savings and deposits, loans, domestic fund transfers, other financial and non-financial services to microfinance clients.

\subsection{Microfinance Bank Target Client}

A microfinance bank target client shall include the economically active low-income earners, low income households, the un-banked and under-served people, in particular, vulnerable groups such as women, physically challenged, youths, micro-entrepreneurs, informal sector operators, subsistence farmers in urban and rural areas.

\subsection{Microenterprise}

A microenterprise is a business that operates with very small startup capital. The management is often built around the sole owner or micro-entrepreneur. It provides employment for few people mainly the immediate family members and does not often require formal registration to start. ,

The management and accounting requirements are very simple and flexible. Generally, most microentrepreneurs work informally, without business licenses or' formal records of their activities. The scope of economic activities of micro-enterprises typically includes primary production and crafts, value added processing, distributive trades and diverse services.

\subsection{Microfinance Loan}

A microfinance loan is granted to the operators of micro enterprises, such as peasant farmers, artisans, fishermen, youths, women, senior citizens and non-salaried workers in the formal and informal sectors. The loans are usually unsecured, but typically granted on the basis of the applicant's character and the combined cash flow of the business and household. .

The tenure of microfinance loans is usually within 180 days (6 months). Tenures longer than six (6) months would be treated as special cases. In the case of agriculture, or projects with longer gestation period, however, a maximum tenure of twelve (12) months is permissible and in housing microfinance, a longer tenure of twenty-four (24) months is permissible.

In line with best practice, the maximum principal amount shall not exceed $\$ 500,000$, or one (1) per cent of the shareholders fund unimpaired by losses and/or as may be reviewed from time to time by the $\mathrm{CBN}$.

\footnotetext{
${ }^{17}$ I.A.Acha, op.cit. p. 108

${ }^{18} \mathrm{CBN}$ Act, No.7, 2007. 'Power to License and Regulate Credit Bureaux'; In furtherance to the provision of s.2(1) of this Act, the bank shall have power to license, and regulate credit bureaux to collect, in such manner as may deem fit, credit information on the customers of Banks and other financial institutions'.

${ }^{19}$ Banks and other Financial Institutions Act, B3. LEN 2004. particularly at S. 62 (a) 'Supervisory Power of the Bank' (CBN). 'The bank shall have power to- supervise and regulate the activities of other financial institutions and specialised banks'.
} 
Microfinance loans may also require joint and several guarantees of one or more persons. The repayment may be on a daily, weekly, bi monthly, monthly basis or in accordance with amortization schedule in the loan contract.

\section{OWNERSHIP AND LICENSING REQUIREMENTS}

\subsection{Ownership Requirements}

- A microfinance bank may be established by individuals, group of individuals, community development associations, private corporate entities and foreign investors.

- No individual, group of individuals, their proxies or corporate entities and/or their subsidiaries shall own controlling interest in more than one MFB, except as approved by the CBN.

A bank holding company that intends to set up any category of MFBs as subsidiaries shall be required to meet the prescribed capital and other requirements stipulated in these Guidelines.

Licensing Requirements

There shall be three (3) categories of MFBs:

Category 1: Unit Microfinance Bank

Category 2: State Microfinance Bank

Category 3: National Microfinance Bank

\subsection{Licensing}

BOFIA $^{20}$ stipulates that every microfinance bank should apply to the CBN for a license to operate. Such application must comply with the conditions provided by CBN, who may at any time vary or revoke any conditions of a license or impose additional conditions.

Where a license is granted subject to some conditions, the MFB shall comply with those conditions to the satisfaction of the CBN within such period, as the CBN may deem appropriate in the circumstances. Any MFB that fails to comply with such conditions shall be guilty of an offence under Section $60(1)$ of BOFIA. ${ }^{21}$

Every licensed MFB shall be required to add "Microfinance Bank" after its name which shall be registered with the Corporate Affairs Commission in compliance with the Companies and Allied Matters Act (CAMA).The font size of all characters in its full name, which shall appear on all banking instruments, signage and sign boards, shall be the same. Failure to comply with this requirement at its Head Office and branches shall attract a penalty of N100,000, N150,000 and N250,000 for Unit, State and National MFBs respectively per office/branch where non-compliance is observed and a warning letter to ensure immediate compliance shall be served.

\subsection{Policy Objectives}

The specific objectives of this microfinance policy $\operatorname{are}^{22}$ :

- Make financial services accessible to a large segment of the potentially productive Nigerian population which otherwise would have little or no access to financial services;

- Promote synergy and mainstreaming of the informal sub-sector into the national financial system;

- Enhance service delivery by microfinance institutions to micro, small and medium entrepreneurs;

- Contribute to rural transformation; and

- Promote linkage programmes between universal/development banks, specialized institutions and microfinance banks.

\footnotetext{
${ }^{20}$ S.59(1) (2) BOFIA, 'Application for License'.

${ }^{21}$ Failure to comply with the conditions of license attracts a penalty of N5,000 each day of default.

${ }^{22}$ Microfinance Policy, op.cit.p.10
} 
The Regulatory and Operational Framework of Microfinance Banks on Consumers in Nigeria: An Appraisal

\subsection{Policy Targets}

Based on the objectives listed above, the targets of the policy are as follows ${ }^{23}$ :

- To cover the majority of the poor but economically active population by 2020 thereby creating millions of jobs and reducing poverty.

- To increase the share of micro credit as percentage of total credit to the economy from 0.9 percent in 2005 to at least 20 percent in 2020; and the share of micro credit as percentage of GDP from 0.2 percent in 2005 to at least 5 percent in 2020.

- To promote the participation of at least two-thirds of state and local governments in micro credit financing by 2015 .

- To eliminate gender disparity by improving women's access tfinancial services by 5\% annually; and

- To increase the number of linkages among universal banks, development banks, specialized finance institutions and microfinance banks by $10 \%$ annually.

\section{FRAMEWORK FOR THE SUPERVISION OF MiCROFINANCE BANKS}

\subsection{Licensing and Supervision of Microfinance Banks}

The licensing of microfinance banks shall be the responsibility of Central Bank of Nigeria. A licensed institution shall be required to add "microfinance bank"; after its name. All such names shall be registered with the Corporate Affairs Commission (CAC), in compliance with the Companies and Allied Matters Act 2004 (CAMA). ${ }^{24}$ This is to give effect to the services being provided by the bank in compliance with the provision of $\mathrm{B} 0 \mathrm{~F} 1 \mathrm{~A}^{25}$ as a company duly incorporated.

\subsection{Establishment of a National Microfinance Consultative Committee}

A National Microfinance Consultative Committee (NMFCC) shall be constituted by the Central Bank of Nigeria $(\mathrm{CBN})$ to give direction for the implementation and monitoring of the policy. Membership of the Committee shall be determined from time to time by the CBN. The Microfinance Support Unit of the CBN shall serve as the Secretariat to the Committee.

\subsection{Credit Reference Bureau}

Due to the peculiar characteristics of microfinance practice, a credit reference bureau, which shall provide information on microfinance clients and aid decision making, is desirable In this regard, Credit Risk Management System in the CBN shall be expanded to serve the needs of the microfinance sector.

\subsection{Deposit Insurance Scheme}

Since MFBs are deposit-taking institutions and in order to reinforce public confidence in them, MFBs shall qualify for the deposit insurance scheme of the Nigeria Deposit Insurance Corporation (NDIC). In accordance with Section 15(1) of the Nigeria Deposit Insurance Corporation (NDIC) Act $2006^{26}$, every licensed MFB shall be required to insure its deposit liabilities with the Corporation, while an insured MFB shall have fidelity insurance coverage up to such level as may be prescribed from time to time by the NDIC. ${ }^{27}$

\subsubsection{Money Laundering}

Every MFB shall be required to comply with the Money Laundering (Prohibition) Act 2011. ${ }^{28}$

\footnotetext{
${ }^{23}$ Ibid, p.11.

${ }^{24} \mathrm{~s} .18,19(1)$ - incorporation of companies

${ }^{25} 5.59$ (1), '... no person shall carry on other financial business in Nigeria other thar insurance and stock broking, except it is a company duly incorporated in Nigeria and holds a valid license granted under S.59 Of this Act'.

${ }^{26}$ Nigeria Deposit Insurance Act; 2006.

${ }^{27}$ S. 33 NDIC Act 2006.

${ }^{28}$ Money Laundering (Prohibition) Act, 2011, for instance in S.1 that has to do with 'limitations to make or accept cash payment'
} 
The Regulatory and Operational Framework of Microfinance Banks on Consumers in Nigeria: An Appraisal

\subsubsection{Disclosure of Sources of Funds}

Licensed MFBs shall be required to disclose their sources of funds, in compliance with the Money Laundering Prohibition Act.

\subsubsection{Management Certification Process}

In order to bridge the technical skills gap, especially among operators of microfinance banks, the policy recognizes the need to set up an appropriate capacity building programme for MFBs. To this end, the CBN shall put in place a microfinance bank management certification process to enhance the acquisition of appropriate microfinance operational skills of the management team of MFBs.

\subsubsection{Apex Associations of Microfinance Institutions}

The establishment of an apex association of microfinance institutions to promote uniform standards, transparency, good corporate practices and full disclosures in the conduct of MFI businesses shall be encouraged.

\subsubsection{Linkage Programme}

The policy recognizes the importance of the provision of wholesale funds for microfinance banks to expand their outreach. Pursuant to this, the CBN shall work out the modalities for fostering linkages between universal/ development banks, specialized finance institutions and the microfinance banks to enable the latter source for wholesale funds and refinancing facilities for on-lending to their clients. .

\subsubsection{Establishment of a Microfinance Development Fund}

In order to promote the development of the sub-sector and provide for the wholesale funding requirements of microfinance banks, a Micro Finance Sector Development Fund shall be set up. 1he Fund shall provide necessary support for the development of the sub-sector in terms of refinancing facility, capacity building, and other promotional activities. The Fund would be sourced from governments and through soft facilities from the international development financing institutions, as well as multilateral and bilateral development Institutions.

\subsubsection{Corporate Governance for Microfinance Banks}

The board of directors of MFBs shall be primarily responsible for the corporate governance of the microfinance banks. To ensure good governance of the banks, the board of directors shall be responsible for establishing strategic objectives, policies and procedures that would guide and direct the activities of the banks and the means to attain same, as well as the mechanism for monitoring Management's performance. Thus, while management of the day-to-day affairs of the banks shall be the responsibility of the Management team, the board of directors shall, however, be responsible for monitoring and overseeing Management's actions. Consequently, the licensed microfinance banks shall be expected to operate under a diversified and professional board.

\subsubsection{Regulatory Incentives}

The new window of opportunity for the emerging microfinance banks in bringing financial services to people who never had access to such services before, would require the support of government and those of regulatory authorities. The CBN shall collaborate with the appropriate fiscal authorities in providing a favourable tax treatment of MFBs' financial transactions, such as exemption from value added tax (VAT) on lending, or tax on interest income or revenue.

Similarly, the principle of exemption from profit tax shall be applied to any MFB that does not distribute its net surplus but ploughs it back and reinvests the surplus to finance more economically beneficial micro, small and medium entrepreneurship.

Furthermore, a Rediscounting and Refinancing Facility (RRF) shall be made available to MFBs for purposes of providing liquidity assistance to support and promote microfinance programmes. This would enable MFBs that have met the CBN prudential requirements to, on a sustainable basis, provide and render micro credits and other services to their clients.

\subsubsection{Other Operational Framework}

Association of microfinance operators notably the National Association of Microfinance Banks (NAMFB) and National Association of Microfinance Institutions (NAMFI) are apex associations of microfinance institutions/banks that promote self- regulation, uniform standards, transparency and 

Appraisal

good corporate governance practices. The associations which are just evolving are expected to also serve as a platform for capacity building, product development and marketing, as well as resource sharing. ${ }^{29}$

The State microfinance apex agencies are government/state owned organizations that attempt to stimulate economic growth within a state by providing institution building support and funds. The funds and support are channeled to specific areas within the state through microfinance operators to drive focused growth and development. These apex agencies provide guidelines that control the operations of the institutions they support and set eligibility and performance criteria for MFIs and MFBs. They provide funding to, and regulate the usage of such funds. ${ }^{30}$

Other institutions that provide ancillary regulatory and supervisory support that impact on the microfinance sub-sector include National Insurance Commission (NAICOM), Securities and Exchange Commission (SEC), Government Ministries and Agencies, among others. ${ }^{31}$

\section{IMPACT OF THE REgULATORY AND OPERATIONAL FRAMEWORK ON CONSUMER}

According to Kofì Annan ${ }^{32}$, former UN Secretary General, 'microfinance has proved its value, in many countries, as a weapon against poverty and hunger. It really can change peoples' lives for the better especially the lives of those who need it most'. However, that a lot of opportunities exist in the microfinance subsector in Nigeria is unarguable. Scholars are unanimous in their agreement that there exist a large untapped market for microfinance banks. Olaitan ${ }^{33}$ buttresses this by pointing out that about $70 \%$ of the Nigerian population is engaged in the informal sector or agricultural production therefore needing the microcredit to do so. Going by the country's population of dyer one hundred and fifty million people we can deduce that about one hundred and five million are in this sector. In the same line though differing in figures, Mohammed and Hassan ${ }^{34}$ in their opinion held that microfinance banks in Nigeria only serve less than one million people against the over 40 million that require their services. The gap in this subsector was further demonstrated by $\mathrm{CBN}^{35}$ when it showed that microcredit facilities in Nigeria account for about 0.2 percent of GDP and less than one percent of total credit to the economy. The scenario above is indicative of an enormous market which microfinance banks can take advantage of. This large untapped market in the microfinance subsector is further enhanced by the fact that over $65 \%$ of the entire population of Nigeria has no access to banking services. To say that this leaves a lot of room for existing microfinance banks to expand their scope of operations and for new ones to enter will be stating the obvious.

An assessment of the microfinance sub-sector, following the launching of the policy however revealed some improvements. These include heightened awareness among stakeholders such as government, regulatory authorities, investors, development partners, financial institutions and technical assistance providers on microfinance. Specifically, a total of 866 microfinance banks have been licensed ${ }^{36}$, and by December, 2017 about 1026 banks licensed. Accordingly, entrepreneurs (consumer) are taking advantage of the opportunities offered by increasingly demanding for financial services such as credit, savings, financial advice and payment services.

The provisions of other regulatory framework including BOFIA, NDIC, CAMA have all impacted positively to the effect that the banks go under as was the .case to the detriment of the consumer. The inclusion of microfinance banks' deposits in the deposit insurance scheme ensures an increasing confidence in the consumers to carry on business with these banks without fear of failure with consequential loss of investment. Again, being an incorporated body, it can sue and be sued therefore where defective services are provided by the banker, the aggrieved consumer retains the right to sue.

\footnotetext{
${ }^{29}$ Draft National Microfinance Development Strategy op.cit. p.13

${ }^{30}$ ibid

${ }^{31}$ ibid

32، International Year of Microcredit 2005', www.un.org/en/events/pastevents/micrcredit 2005. Accessed $21 / 9 / 2014$.

${ }^{33}$ M.A.Olaitan, Finance for Small and Medium Enterprises: Nigeria's Agricultural Credit Guarantee Scheme Fund. Journal of Farm Management, 3(2), (2006), p.1-9

${ }^{34}$ A.d.Mohammed and Z.Hassan, 'Microfinance in Nigeria and the Prospect of Introducing an Islamic Version in the light of Selected Muslim Countries’ Experience'. Review of Islamic Economics (2009), 13(1), p.115

${ }^{35} \mathrm{CBN}$ Microfinance Policy, 2005, op.cit

${ }^{36}$ Microfinance Policy Framework for Nigeria, p.7
} 

Appraisal

The policy has increased savings opportunity although still restricted to semi urban areas since these microfinance banks are still none existent in most rural settings. Poor consumer can and do save, contrary to general misconceptions although a lot more need to be done as most consumers still keep their resources in kind or simply under their pillows. Such methods of savings are risky, low in terms of returns and undermine the aggregate volume of resources that could be mobilized and channeled to deficit areas of the economy.

The microfinance policy provides the needed window of opportunity and promotes the development of appropriate (safe, less costly, convenient and easily accessible) savings products that would be attractive to rural clients and improve the savings level in the economy.

The establishment of a Microfinance Policy Framework for Nigeria provides an opportunity for local and international investors to participate $i n$ financing the economic activities of low income groups and the poor. Most of the existing banks are located in urban centers, and several attempts in the past at encouraging them to open branches in the rural areas did not produce the desired results. With a high proportion of the Nigerian population still living in the rural areas, it has become absolutely imperative to develop an institutional framework to reach the hitherto unserved population with banking services. Consequently, it is suggested that the provision regulating the establishment of a microfinance bank should be restricted to the rural community.

Most targets of microfinance banks are uneducated, not informed on issues of banking, insurance, ATM and other services usually provided by Microfinance institutions. Oftentimes they just respond to conditions imposed by the service provider which may not necessarily meet their needs. In order to ensure that service providers do not take undue advantage of the customers' financial literacy levels, Service providers should seek and secure approvals of their products and services from the regulatory body. The conditions and services must be displayed in the meeting places and or banking halls and confirmed as approved by the regulatory body. ${ }^{37}$ To be of immense advantage to the consumer, Microfinance institutions must explain terms and condition of services being offered to the clients (consumer) and ensure that they understand them before commitments are made. While customers are responsible largely for their financial commitments, it will now form part of the responsibility of the lenders to ensure that customers are not pushed to over- borrowing when they understand the terms to encourage compliance.

For the benefit of the consumer, Regulatory body will only approve products and services with conditions that do not infringe on the customer's right and that is fair in business dealings. Available evidences point to the need to specially slant microfinance services in favour of the female gender, the physically challenged and the rural dwellers. Not only are these people the most discriminated against in terms of access to finance, they (especially the women) are ironically better microfinance clients, posting better repayment records than men and using the benefits of improved income more for household than for personal needs. ${ }^{38}$

Summarily however, more than 17 years after its introduction, microfinance banks are yet to operate in line with sound-banking realities. Pricing of their products and services evidenced by high interest rate and other charges; poor degree of service delivery, volume of credits, business and branches very low. Moreso, the consumer service/affair's department is yet to be established and full electronic banking system operationalized.

\section{The Challenges of Microfinance Banks in Nigeria}

As highlighted in the previous section, the failure of community banking scheme and many previous government's micro financing schemes were predicated on the challenges they faced. Many of these challenges are still bedeviling ${ }^{39}$ microfinance banks and include though not limited to the following;

\footnotetext{
${ }^{37}$ Draft National Microfinance Development Strategy. P.59

${ }^{38}$ N.C.IrobI,'Microfinance and poverty Alleviation: A Case Study of Obaze Progressive Women Association, Mbieri, Imo State- Nigeria'. Uppsala. Department of Economics (2008).

${ }^{39}$ J.O.Nwanyanwu Microfinance in Nigeria: Problems and Prospects'. African Research Review, (5(2),2011), p.87.
} 


\subsection{Infrastructure}

One of the most fundamental difficulties microfinance banks in Nigeria have is the near absence of basic infrastructure. This lack of basic infrastructure compounds the operational difficulties of these banks. They are found occupying small structures most times without conventional facilities and very small working space that cannot provide the required standard of a good working environment. In such circumstances, the service providers may find it difficult to give their best to the dissatisfaction of the consumer who in turn may not have any reason going back even though it is in his own advantage.

\subsection{Operational Funding}

Microfinance banks ordinarily are faced by high operational costs because of their nature of business. By dealing with many small clients microfinance banks' transaction costs are usually higher than those of conventional banks. Unfortunately, these banks are also forced to incur additional costs to provide themselves with electricity and water. The absence of good roads especially in the rural areas also distorts their outreach. ${ }^{40}$ All these work in concert to drive cost of operations up and put them at a very big competitive disadvantage.

\subsection{Banking Culture}

The lack of banking culture in the rural areas and among the urban poor is another factor militating against the progress of microfinance banks. Traditionally, these people borrow money from friends and relatives and repay the same amount of money borrowed no matter the tenure of such loans. They therefore find it difficult to understand the payment of interest on bank loans. In the northern part of the country, the issue of frowning at interest on loans takes a religious dimension. This part of the country is populated by mainly Muslims, a religion which abhors usury. This has hampered the development of microfinance banking in that part of the country. This was buttressed by Akpan ${ }^{41}$, who opined that "conventional micro-financing violates Islamic principles by charging interest. In addition to this, Islamic banks are being licensed and may end up in the same market segments as microfinance banks. The rate of interest charged by microfinance banks leaves a lot to be desired. According to a study carried out, microfinance banks charge between 30\% 100\% interest on loans while they pay $4.5 \%$ to $6 \%$ on savings. ${ }^{42}$ Anyanwu $^{43}$, confirmed that the microfinance banks rates are way too high and may not augur well for the smooth development of this sector.

\subsection{Government Policy}

The failure of many community banks and the withdrawal of the licence of 224 microfinance banks in 2010 have badly damaged public confidence in these banks ${ }^{44}$. Many microfinance banks established in communities where failed community banks existed are faced with an uphill task of convincing these communities that they will not go through the unfortunate experience of losing money in a bank failure. The sudden withdrawal of the license of these banks has fuelled the lack of public confidence which community banks bequeathed them. Many of the customers of these banks have refrained from dealing with them in fearing the same fate would befall them. On the other hand, the Central Bank of Nigeria has constantly assured the public that it will not allow any commercial bank to fail; this, places the microfinance banks at a great disadvantage by tilting public confidence in favour of commercial banks that are normally bigger and stronger.

The constant government policy changes offer its set of challenges to the microfinance banks. ${ }^{45}$ In 2007, commercial banks were consolidated; they became so big obviously leaving the not too wealthy client segment to microfinance banks. Today banks have been reclassified into regional, national and

\footnotetext{
${ }^{40}$ M.Yunus, op.cit.

${ }^{41}$ I. Akpan, Fundamentals of Finance, (UYO: Abaam publishing co. 2009), 3 . Ed. p.22

${ }^{42}$ UNDP, 'Development of a Sustainable Pro-poor Financial Sector, Phase Il Micro Start Nigeria. http;//www.uncdf.org. accessed 3 September, 2014.

${ }^{43}$ C.M.Anyanwu 'Microfjnance Institutions in Nigeria: Policy, Practice and Potential. Nigeria: Central Bank of Nigeria Research paper, (2004), p.1-3.

${ }^{44}$ A.A. Ikechukwu, op.cit. p.108.

${ }^{45}$ K.S.Adeyemj, 'Institutional Reforms for Efficient Microfinance Operations in Nigeria'. Central Bankof Nigeria. Bullion, (2008), 32(1), p.26 .
} 
The Regulatory and Operational Framework of Microfinance Banks on Consumers in Nigeria: An Appraisal

international, fuelling fears that the regional banks might be in direct competition with microfinance banks. ${ }^{46}$

\subsection{Human Resource}

Another important factor identified to militate against the performance of microfinance banks in Nigeria as identified is limited support for human an institutional capacity building ${ }^{47}$. The paucity of human capacity in the microfinance sub-sector in Nigeria has been an issue from the days of community banking. According to Ikeanyibe ${ }^{48}$, one of the major problems of the microfinance subsector is recruitment of effective and appropriate manpower. This he ascribed to the inability of the sector to adequately remunerate staff. Other human resource problems faced by microfinance banks include lack of training opportunities and poor conditions of service. The quality of manpower in these banks is reflected in the poor performance of many of them, inefficiency and high levels of frauds and forgeries. The banks also suffer from high labour turnover, a further indication of low staff motivation and poor personnel practices. Many microfinance bank managers and other management staff were commercial banks' staff who were either retired or sacked by their former employers. To these staff microfinance banking is just an extension of the commercial banking they know. They also come with their organizational orientation, philosophy and culture. They refuse to understand that microfinance is not micro-commercial banking but a different kind of banking requiring a different approach, philosophy and client base. They also engage in inordinate competition with the commercial banks. This class of staff lack orientation as to the essence of microfinance.

\subsection{Corruption}

Corruption is a cankerworm that has wrecked-havoc in many sectors of the Nigerian economy. The microfinance sub-sector is not left out of the ravages of corruption. ${ }^{49}$ This manifests in many ways, such as, corporate governance failures, frauds and forgeries, theft and refusal by customers to repay loans. The standard of corporate governance in many microfinance banks in Nigeria is poor. Board members are known to misuse their positions to obtain facilities way above the regulatory limit for insider related loans and worse still with no intentions of repaying such facilities. They also use their positions to unduly influence and manipulate the recruitment processes in favour of their cronies. Frauds and forgeries by both insiders and outsiders to the banks are rife and people generally obtain loans with no intention to repay.

\section{CONCLuSion}

Nigeria is a country with enormous resources, unfortunately despite this a great number of Nigerians still live in poverty. It is in the bid to address this that the CBN formulated the microfinance policy guidelines in 2005. This guideline among other things provided for the licensing of microfinance banks. The microfinance banking subsector in Nigeria is therefore relatively young having taken-off in 2007. Like many new ideas, it is undergoing a challenging and trying period. With the Microfinance Policy in place, it has assisted in improving the socio economic standard of a negligible percentage of the consumer of its services. This failure in our opinion is due to the fact that the microfinance banking services is still restricted to the urban and semi urban areas as against its intention of targeting the poor consumers in the rural areas. Again, there are some challenges facing microfinance banks in Nigeria as were experienced by the numerous poverty alleviation programmes set up in the past which led to their failures. Such include; regular changes in government policies, lack of requisite human capital, infrastructural inadequacies and socio-cultural misconceptions.

In addition to these, the banks are further inhibited by corruption, fraud and clients with poor financial power. To address these issues concerted efforts on the part of regulators, promoters, practitioners and other stakeholders in the microfinance banking subsector is required. This is to ensure that they do not drag the subsector under as was the case of previous microfinance schemes of government. It is

\footnotetext{
${ }^{46}$ A.A. Ikechukwu, op.cit. p. 108

${ }^{47} \mathrm{CBN}$, Microfinance policy, op.cit.

${ }^{48}$ O.M. Ikeanyibe, 'Human Resource Management for Sustainable Microfinance Institutions ¡n Nigeria', Global Journal of Social Sciences, (2009),p. 119.

${ }^{49}$ A.A.Ikechukwu, op.clt.p. 108
} 
The Regulatory and Operational Framework of Microfinance Banks on Consumers in Nigeria: An Appraisal

generally appreciated that there would be need for a new legislation to provide for the peculiarities of microfinance banks.

\section{RECOMMENDATIONS}

To enable microfinance banks in Nigeria take advantage of the enormous market potentials, the following suggestions to mitigate the challenges they face are advanced:

Conscious efforts to take microfinance banking to the rural community where they are meant for should be of priority to the operators of this policy, to the effect that no microfinance bank or a minimum of one should be sited in the urban area.

The capacity building for the practitioners which the CBN and NDIC are undertaking is a welcome development and should be extended to the Board of Directors of these banks. This will ensure that the Directors who craft the policies for these banks are on the same page with their management staff. They should be made to understand the operational limits, modalities and objectives of microfinance banks. Particularly, they should be made to realize that these banks are not mini commercial banks and that microfinance banks pursue social motives in addition to financial sustainability.

Since poor banking culture is one of the fundamental problem plaguing microfinance banking in Nigeria, it becomes expedient that these banks should train their clients in financial literacy before disbursing loans to them. The clients should be made to understand the intricacies of such facilities, including repayment mode, interest charges and benefits of keeping to the terms of the credit contract.

Furthermore, the National Assembly should as a matter of urgency and in collaboration with the CBN commence the process for enactment of an organic legislation for microfinance banks in the country. The legislation to be enacted should take cognizance of pricing of products and services, amount of credit allowable and tenor, deliberate rural branches and expansion and provision of a consumer service department.

Moreover, steps should be taken by microfinance banks to expand the e-banking coverage in their service to be in tandem with world best practices.

\section{REFERENCES}

[1] Acha, I. A. 'Microfinance Banking in Nigeria: Problems and Prospects' International Journal of Financing and Accounting, 1(5), (2012).

[2] Adeyemj, K.S. 'Institutional Reforms for Efficient Microfinance Operations in Nigeria'. Central Bank of Nigeria. Bullion, (2008).

[3] Akpan, I. Fundamentals of Finance, (UYO: Abaam publishing co. 2009), 3rd Ed

[4] Anyanwu, C. M. 'Microfinance Institutions in Nigeria: Policy, Practice and Potential. Nigeria: Central Bank of Nigeria Research paper, (2004)

[5] Eboh, E.F. 'Changing Development Paradigms via Microfinance Banks', African Journal of Entrepreneurship, 1(1), (2008).

[6] Ikeanyibe O. M. 'Human Resource Management for Sustainable Microfinance Institutions in Nigeria', Global Journal of Social Sciences, (2009).

[7] lorchir, D. 'Reducing Poverty in Benue State of Nigeria: The Role of Microfinance and MicroEnterprises', Journal of Business Management 1(2), (2006)

[8] Irobi, N. C. 'Microfinance and Poverty Alleviation: A Case Study of Obaze Progressive Women Association Mbieri, 1mo State Nigeria'. Uppsala, (2008.) .

[9] Mohammed A.D. and Hassan, Z. 'Microfinance in Nigeria and the Prospect of Introducing an Islamic Version in the light of Selected Muslim Countries' Experience'. Review of Islamic Economics (2009). .

[10] Nwanyanwu O. J., 2011, Microfinance in Nigeria: Problems and Prospects. African Research Revjew, $5(2)$.

[11] Okpara, G. C. 'Microfinance Banks and Poverty Alleviation in Nigeria', Journal of Sustainable Development in Africa, (2010).

[12] Olaitan, M. O. Finance for Small and Medium Enterprises: Nigeria's Agricultural Credit Guarantee Scheme Fund. Journal of Farm Management, 3(2), (2006). .

[13] Yunus, M. \& Alan, J. 'The Banker to the Poor: Micro-lending and Battle against World Poverty', Public Affairs, (1999) 
The Regulatory and Operational Framework of Microfinance Banks on Consumers in Nigeria: An Appraisal

\section{STATUTES/ GUIDELINES}

Banks and other Financial Institutions Act, B3. [FN 2004

Central Bank of Nigeria Act, No.7, 2007

Draft National microfinance Development Strategy' (for discussion and comments only)

'International Year of Microcredit 2005', www.un.org/en/events/pastevents/microcredit, 2005, Accessed 21/9/2014.

Microfinance Policy Framework for Nigeria

Microfinance Policy Regulatory and Supervisory Framework for Nigeria',(Abuja: Central Bank of Nigeria, 2005) revised 2012

Money Laundering (Prohibition) Act, 2011.

Nigeria Deposit Insurance Corporation Act, 2006

UNDP, 'Development of a Sustainable Pro-poor Financial Sector, Phase II Micro Start Nigeria. http;//www.uncdf.org. Accessed 3/9/2014.

\section{AUTHOR'S BIOGRAPHY}

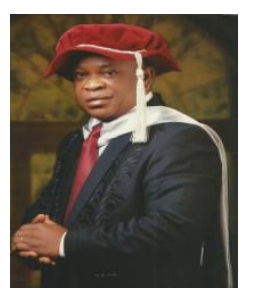

Dr. Jacob Otu Enyia is a Barrister and Solicitor of the Supreme Court of Nigeria and a senior lecturer in the department of Commercial and Industrial law in the University of Calabar, Calabar-Nigeria. He has authored so many Articles in both local and international journals and a specialist in Consumer Protection Law and Commercial Law. He is also developing and researching in the area of Telecommunications and Banking Law.

Barrister Inyang, Patricia Endeley is a Lecturer in Law at the Faculty of Law, University of Calabar and a Barrister and Solicitor of the Supreme Court of Nigeria. She specializes in International Commercial Law.

Citation: Enyia, Jacob Otu, Inyang, Patricia Endeley. “ The Regulatory and Operational Framework of Microfinance Banks on Consumers in Nigeria: An Appraisal" International Journal of Managerial Studies and Research (IJMSR), vol 6, no. 7, 2018, pp. 1-13. doi:http://dx.doi.org/10.20431/2349-0349.0607001.

Copyright: () 2018 Authors. This is an open-access article distributed under the terms of the Creative Commons Attribution License, which permits unrestricted use, distribution, and reproduction in any medium, provided the original author and source are credited. 